\section{Meaning and context in political theory}

\section{Albert Weale $\mathbb{D}$}

University College London, UK
European Journal of Political Theory

$0(0)|-| 1$

(C) The Author(s) 2020

(c) (1) (8)

Article reuse guidelines: sagepub.com/journals-permissions DOI: I0.II77/I474885I20925375

journals.sagepub.com/home/ept

Eric Nelson, The Theology of Liberalism: Political Philosophy and the Justice of God, Cambridge, MA and London: Belknap Press, 2019; xii + 218 Pp.: $€ 23.95$, ISBN 978-0-67424-0940, hbk

Katrina Forrester, In the Shadow of Justice: Postwar Liberalism and the Remaking of Political Philosophy, Princeton, NJ and Oxford: Princeton University Press, 2019; xxii + 40 I pp.: $£ 30$, ISBN 978-0-69 I- I6308-6, hbk

\begin{abstract}
The two books offer a contextual reinterpretation of Rawlsian and post-Rawlsian liberalism. Nelson's main thesis is that debates in liberal political theory re-enact theological debates about theodicy going back to the Pelagian controversy. This claim is criticized for its historical inaccuracy. Nelson's invocation of theodicy as a refutation of luck egalitarianism and the Rawlsian rejection of desert rest on a claim of possibility that is too weak to uphold a plausible refutation. Forrester locates Rawls's rejection of desert in the thinking of his contemporaries. She not only shows the development of Rawls's thought but also details its broad influence. However, her thesis that the role of economic planning in a theory of justice remained undeveloped by Rawls ignores the intrinsic difficulties of designing a system of economic planning. The persistent antinomies of grace and free will in metaphysics, and of planning and the price mechanism in economics, show the continuing relevance of meaning beyond context.
\end{abstract}

\title{
Keywords
}

desert, liberalism, modern political theory, theodicy, theology

\section{Corresponding author:}

Albert Weale, University College London, 29/3I Tavistock Square, WCIH 9QU, London, UK.

Email: a.weale@ucl.ac.uk 


\section{Introduction}

The dominant approach in modern normative political theory focuses on the analysis of concepts and principles, the meaning and justification of which are claimed to follow from certain assumptions. Those concepts and principles are then tested against intuitions, counterexamples or body of theory. The relevant chains of reasoning are treated as though the texts in which they are written are self-contained. By contrast with this approach, historians of political thought, particularly those influenced by Quentin Skinner (see Tully, 1988), have insisted that the study of texts is incomplete without the study of context. This might seem simply to reflect a distinction between contemporary thought on the one hand and past thought on the other. Meaning for the present; meaning and context for the past. The significance of the two books under review - different in so many ways is that both invite us to study the present as though it were the past. They each suggest that understanding meaning requires the understanding of context. If persuasive, their approach would mark a radical shift in the methods of contemporary political thought. How well do they vindicate their alternative approaches?

\section{Liberalism and theodicy?}

The central thesis of Nelson's book is that modern political theorists 'have been unwittingly taking up positions in the theodicy debate' (p. xi). Theodicy is concerned with the question of how the existence of evil in the world is compatible with the existence of an all-loving and all-powerful God. Augustine's answer was that all evil was either sin or punishment for sin, a view dominant in western Christianity ever since (see Hick, 1968: 178-179). Augustine thought that human beings were so mired in original sin that their salvation required the grace of God, and could not be achieved by their own works. In pursuit of this doctrine, he opposed the views of Pelagius, who stressed the importance for Christians of good works flowing from a will seeking perfection.

The place at which this debate from the early fifth century CE touches modern political theory is in Rawls's senior thesis, A Brief Inquiry into the Meaning of Sin and Faith (Rawls, 2009). Brief Inquiry adopts an explicitly anti-Pelagian position, rejecting the idea that human beings merit salvation. From this Rawlsian starting point, Nelson argues that the Augustine/Pelagius controversy is played out more widely in the development of liberal political theory. He suggests that, from the early modern period onwards, most liberal thinkers adopted a Pelagian position. Rawls's anti-Pelagianism opposed that long-standing trend and presages a debate about cosmic injustice arising from luck egalitarianism.

Brief Inquiry offered two reasons for rejecting merit as a ground of just treatment. Firstly, reflecting on their gifts, individuals should realize what they owed to others. Good fortune, for example, comes from family love. Secondly, Rawls offered an explicitly theological reason for rejecting merit, drawn from neoorthodox Protestant theology of the early 20th century: '... there is no man so 
upright that the Word of God beside his goodness will not condemn' (Rawls, 2009: 240). In Theory, Rawls seems to recapitulate the non-theological elements of these themes, asserting that a good character depends upon the family in which someone grows up and that it is a matter of mere contingency where any one person ends up in the natural distribution of skills and talents. Even the disposition to effort is a given. Offered as part of the justification of the difference principle, these considerations support the claim that, in justice as fairness, the parties to the contract agree 'to regard the distribution of natural talents... as a common asset...' (Rawls, 1999: 87).

Given these parallels, it is not surprising that commentators have suggested that Brief Inquiry anticipates the arguments in Theory. Cohen and Nagel (2009: 18-19) assert 'a particularly striking continuity' between the undergraduate dissertation and Rawls's later views. They go on to suggest that, though the claims are linked to revelation in the dissertation, they 'can be given a purely secular significance'. Nelson, by contrast, proposes that 'Rawls in fact offers a paradigmatic case of the perils of secularization', because 'when religious arguments are secularized, they tend to leave behind the set of premises that initially made sense of them' (p. 67). Yet, he too holds to a continuity thesis, saying that the mature position of Rawls 'essentially replicates' (p. 63) the view in the senior thesis. If Cohen and Nagel propose we secularize the theological, Nelson holds that we should theologize the secular. As he puts it: 'The point is not that the mature Rawls continued to accept the doctrine of original sin, but rather that he continued to write and think as if he did' (p. 69; emphasis in original).

The thesis that debates in modern political theory re-enact the theodicy debate is a bold one, but cannot be plausibly sustained for a number of reasons. The first is that the theology on which Rawls drew in his senior thesis was historically mistaken about the dispute between Augustine and Pelagius. That dispute was represented as one between Augustine's view that Adam's original sin was transmitted to the whole of humanity, which only God's grace can redeem, and the Pelagian view that no such transmission took place, and that human beings are capable of salvation through good works as the result of free will. However, from the mid-20th century onwards, a large body of scholarly work has shown that Pelagius was not the proto-Enlightenment liberal painted by neo-orthodox Protestantism (see, for example, Evans, 1968 and Rees, 1988). Instead, Pelagius was an ascetic who urged renunciation and the divestment of wealth among Christians newly converted from the Roman nobility, as he did in his letter To Demetrias, a 14 year old Christian woman from a upper class Roman family who renounced marriage for the sake of a pious life of virginity (Pelagius, 1991 [413], one of his few well-attested writings). Purity of heart was a cardinal virtue for Pelagius (ironically perhaps in the same way that it was central to Rawls's (1999: 514) account of the virtue of the just person). The putatively heretical propositions attributed to Pelagius are typically drawn from the writings of his opponents, who were not fastidious when ascribing views to those they condemned. One recent study points out that, of the fourteen supposedly heretical propositions ascribed to 
Pelagius by Augustine (1971 [417]: 211), fewer than two can be found in the reliably attested writings of Pelagius himself (Bonner, 2018: Chapter 2), no elements of which were heretical at the time. In short, 'Pelagianism' functions as an empty signifier, rather like 'neoliberal' in much modern political theory.

Nelson is aware of how little we know about the historical Pelagius (p. 168, n. 7) and this makes it all the more strange that he uses the term 'Pelagian' to characterize the growth of liberalism, from the early modern period. In effect, the label is being used to signal the liberal revolt against the idea that a just God could act in an arbitrary manner. Moreover, although Pelagius and Augustine did differ over the issues of God's grace and its relation to the freedom of the human will, their dispute is an unreliable basis for interpreting contemporary discussions about justice, not least because there is enormous controversy as to what Augustine's doctrine of the human will was, and whether it can be adequately reconstructed. One commentator notes that Augustine's position is so variously interpreted from determinism to voluntarism - that it is difficult to believe that historians are reading the same texts (Stump, 2001: 166). Nelson is, in effect, offering a heuristic for liberal political thought based on a non-historical Pelagianism and a hard to reconstruct Augustinianism.

What role does the specific idea of a theodicy play in Nelson's analysis? This is most clearly seen in his critique of the luck egalitarian claim that justice requires compensation for unchosen disadvantages arising from the unequal distribution of natural talents and abilities. One answer to the problem of theodicy is to deny that evil really exists once its character is rightly understood. Alexander Pope expressed this thought clearly in the Essay on Man, when he wrote that 'all partial evil' is 'universal good'. Nelson adopts the parallel strategy in his deployment of theodicy arguments against luck egalitarianism, in which he concludes that the "problem with luck egalitarianism... is not that we are unable to correct the injustice it identifies; it is that we cannot know whether there is an injustice to correct' (p. 103). To derive this conclusion, Nelson seeks to catch the luck egalitarian in a dilemma: 'either the distribution of natural endowments and advantages can be unjust, or there is a God' (p. 81). However, if there is a God, the world might be designed in accordance with what Nelson calls a 'Cosmic Difference Principle' (p. 91). For example, person A's greater intelligence compared to person B may be necessary for A to develop the life-saving medicine that helps B.

Nelson has no difficulty showing that the luck egalitarian cannot plausibly refute this possibility, from which he infers that no unfairness can be ascribed to divine design, and therefore the natural injustice that luck egalitarians invoke does not exist. However, this is to employ a very weak notion of possibility to underpin a very demanding thesis. The possibility of a necessity is no more than a possibility. It is possibility in the same sense in which it may be possible to find hidden pearls of wisdom in the tweets of Donald Trump. None of this is to say that luck egalitarianism is plausible. Nelson (pp. 73-74) offers a very good summary of the decisive objections to its claims. It is to say that the refutation by theodicy does not add to those objections. 
Nelson also applies his method to what he terms the institutionalist reading of Rawls, according to which reference to the morally arbitrary is a way of stating the irrelevance of individual differences to fundamental social and political purposes (citing Scheffler, 2003: 22). Nelson rejects this approach because he thinks it ignores the possibility that the distribution of natural advantages is not arbitrary from the moral point of view. From the point of view of a theodicy, we should say 'who knows?' (pp. 111-112 and 132).

This line of critique fails because it rests on a pervasive assumption on Nelson's part that the political positions to which he objects tacitly invoke a denial of a theological possibility. This lies behind his claim that, though Rawls gave up his belief in original sin, he continued to write as if he still believed it, as well as his claim that:

to say that the existing distribution of well-being and natural advantage among human beings is unjust or unfair is to say that, had the distribution been intentionally brought about by an agent, that agent would be guilty of injustice or unfairness. (p. 75)

One problem here is that the argument appears to rely on treating the justice and injustice of the natural distribution as contradictories (clearly both claims cannot be true), whereas they may be contraries (both claims could be false), which would be so if the natural distribution were neither just nor unjust, but merely irrelevant. However, it also seems to rest on a version of the fallacy of affirming the consequent. It may be that the premises of the argument against the merit in Brief Inquiry cannot be secularized, but it does not follow from that truth, if it is one, that there are no secular premises that lead to the same conclusion.

What would a secular derivation of an egalitarian account of justice look like? Consider the following. Rawls (1999: 5) took from Hart (1961: 155-159) the idea that justice involves treating like cases as like, with grounds of different treatment resting on relevant reasons. Hart's claim went back at least as far as Sidgwick's discussion of the 'common sense' idea of justice in The Methods of Ethics (Sidgwick,1981 [1907]: Book III, Chapter V). Sidgwick pointed out that justice requires that in laying down the law, 'all inequality affecting the interests of individuals which appears arbitrary, and for which no sufficient reason can be given, is held to be unjust' (Sidgwick, 1907: 267-268). Could desert be a sufficient reason for difference of treatment and so be a non-arbitrary basis for distribution? In a series of claims that are a remarkable anticipation of Rawls, Sidgwick points out that we cannot easily reward someone as deserving because the utility of their service may have been developed by favourable conditions of life or by a good education. Good dispositions and habits are partly inherited and partly due to the care of parents and teachers. If we take a deterministic view of human nature, voluntary effort will not provide a basis of desert. And we cannot separate in practice that part of a person's actions that is due to free choice from that part which is due to the original gift of nature. I am not claiming that Rawls was influenced directly by 
Sidgwick in the discussion of desert. Although he cites Sidgwick's chapter in Theory (Rawls, 1999: 83), the relevant citation occurs as one source for the liberal interpretation of the career open to talents, not as part of his discussion of desert. However, Sidgwick's discussion does show how the claims of desert may be qualified, based on an analysis of what 'justice' is taken to mean.

In the intellectual and political context within which Rawls wrote Theory, there was widespread acceptance of views like those of Hart and Sidgwick. In Equality, a text that Rawls knew, RH Tawney (1964: 84-85) pointed out that the inequality which egalitarian thinkers deplored 'is not inequality of personal gifts, but of the social and economic environment'. Although Tawney wrote as a Christian socialist, he located his account of equality in a broad humanism that was not the exclusive possession of either those who reject or those who accept some body of religious belief. Rawls's rejection of desert echoes those intellectual traditions.

\section{Principles without politics; politics without principles?}

As Katrina Forrester (pp. 110-116) points out, A Theory of Justice was published against what Barry (1965: 112-115) called 'the revolt against desert', exemplified for Barry in those welfare states that catered for the underserving poor. Tracing the way in which Rawls built up his theory since the 1950s, she notes how ambitious it was, aspiring to encompass an account of objective morality, the replacement of utilitarianism and a statement of the principles of liberal constitutionalism. However, it was debates about the welfare state that created the audience for the book, involving as they necessarily did controversies about the state and its proper limits. Those debates also shaped the various ways in which Theory was received, with some seeing it as a vindication of an activist redistributive state, some seeing it as the harbinger of socialism and yet others seeing it as merely restating the basic principles of liberalism. Theory meant many different things to many different people (p. 105).

Through an extensive use of Rawls's own papers and archival material, Forrester shows how Rawls's early thinking (post his theological phase) represented a form of anti-statism, drawing on a Tocquevillean account of democratic community and a Jeffersonian emphasis upon the broad distribution of property as a precondition for the independence of citizens. During the 1950s he left behind this barebones liberalism, but the structure of theory that he built rested on a consensual vision of ethics and society (Chapter 1). Moreover, as Forrester notes, Rawls was a great syncretist, drawing into his theory concepts from game-theory, rational choice, Keynesian public finance and Kantian ideas of moral autonomy. (In this respect, I think, he was like John Stuart Mill, who could not resist a good idea no matter how inconsistent it was with the other ideas he held.)

What, then, were the characteristic features of Rawls's theory that cast such a long and broad shadow? According to Forrester (pp. 107 and 132), they comprised a focus on institutions and institutional rules, the priority of justice over humanity, 
a framing of justice in terms of distribution, a focus on moral persons as the basic unit of justice, an assumption of human equality, a vision of society in which social cooperation is central and for which stability is to be sought and a side-stepping of historical arguments so that how people came to be located in unjust situations was deemed unimportant. Moreover, because the method of the original position had to abstract from the lived experience of actual individuals, the approach was necessarily impersonal. From its publication, this constellation of elements defined the scope of permissible arguments in political philosophy, drawing in, for example, Marxist theorists, who might otherwise have been concerned with the political struggle over the means of production (pp. 214-218). Yet, since there was a strand of Rawls's theory, going back to his earlier years, that focused on the moral personality in community, even his communitarian critics, like Taylor and Sandel, in some ways echoed ideas that he himself had originally held (p. 268).

Although the publication of Theory is sometimes presented as a philosophical bolt from the blue coming out of nowhere, Forrester's account reveals the political context that provided the spur for Rawls's own work. Particularly important here were the many Oxford academics, like Hart and Berlin, who had links with the Labour Party in the 1950s, and whom Rawls came to know from his visit in 19521953 (pp. 18-25). Forrester notes the continuing relevance of the revisionist controversy in the Labour Party in the 1950s (p. 118) persisting into the 1980s.

Forrester's central claim is that Rawls's theory never came to terms with the ending of the political context of post-war stability in which it was fashioned. The effects of the civil rights movement and the war in Vietnam were to disrupt a social and political order that was based upon a value consensus supported by economic growth (Chapters 2 and 3). The OPEC oil price crisis, the ending of the Bretton Woods era and the emergence of environmental concerns in effect transformed the political dynamics of the world that Theory presupposed. The rise of the New Right and the New Left, along with anticolonial and feminist movements, meant that there was no value consensus to underpin the constitutional essentials of a Rawlsian social and political order. In effect, Forrester argues that Rawls's theory promised a better yesterday.

Yet, Rawls's work came to define the dominant terms of acceptable debate within political philosophy in the form of a liberal egalitarian paradigm. Not only was it an influential body of idea within its own self-declared domain constitutional politics and the constitution of the economy - but it provided the framework in which others could extend the theory to questions of international and intergenerational justice. Even when theorists went beyond the terms of Rawls's own thinking, that thinking provided the foil against which counterideas could be tested. Subsequent work was in the shadow of justice.

For Forrester, the price paid for this intellectual hegemony was a political insensitivity to radical, emancipatory and progressive political movements. Rawls was resistant to identifying his own theory with a particular position on the ideological spectrum, saying that it was compatible with forms of market socialism as well as the property-owning democracy (p. 117). Forrester suggests 
that its abstract method meant that it could not encompass the claims of identity politics. Its methodological individualism meant that it neglected the context of institutions, so that its extensions, for example in Dworkin's clam shell auction and hypothetical insurance market (pp. 209-210), lacked realistic application to the problems of poverty and ill health. Its lack of attention to historical situatedness meant that it could not deal with issues of reparations for colonial and racial wrongs (pp. 132-135). It did not acknowledge the legitimacy crisis of the state that followed the breakdown of the post-war consensus. Most importantly of all, it became detached from the politics of the labour movement, lacking the theoretical capacity to provide guidance on the democratic control of the economy and society at large (pp. xix, 4, 237, 268-269). The egalitarians that Rawls's work inspired 'became the defenders of a dying breed of universalizing, redistributive, statefocused politics...' (p. 273).

This critical evaluation is the most important upshot of Forrester's historical method. It is a claim about how meaning, detached from context, remains inert, abstract and unhistorical. The natural implication one would draw from this judgement is that, despite its intellectual hegemony over the last 50 years, Rawlsian theory should be consigned to the scrapheap of history. In the end, Forrester recoils from this stark conclusion, saying that liberal egalitarianism has aspects that can make it the beginning, if not the end, of political reform (p. 278). Yet, the basic indictment remains. How well founded is it?

Many issues might be taken up here, but for reasons of space I shall focus solely on two, relating to how a Rawlsian abstract analysis may be linked to substantive politics. Consider first the political programme that might be associated with a theory of justice. At a number of points, Forrester criticizes the lack of connection between Rawlsian liberal egalitarianism and a politics of democratic control, particularly one rooted in the labour movement (for example at pp. 207 and 237). However, the meaning that Forrester attaches to the idea of democratic control is never clarified. The issue is presented as a simple dichotomous choice between planning and the price mechanism. Yet, this is to ignore the need to balance the two within the design of a viable political economy. The best general discussion of these design problems still remains Alec Nove's (1983) The Economics of Feasible Socialism, not only because of Nove's immense learning in Marxist economic theory, but also because of his familiarity with the debates about economic planning and organization in the Soviet Union and Yugoslavia. The burden of his analysis is that the pursuit of planning needs to come to terms both with economic scarcity, and the opportunity costs scarcity implies, as well as with the informational needs of a large-scale and complex economy in which only a decentralized price system can coordinate economic activity in a way that avoids major waste of productive effort.

One way of seeing Rawls's favouring of a property-owning democracy over the welfare state is to see it as a way of working through these intrinsic problems of balancing planning and the price mechanism. Rawls's (1999: 239-242) agnosticism about how far his theory was compatible with forms of both socialism and 
capitalism can be seen as a way of accepting the need for analysis at a high level of abstraction, whilst rejecting the view that one can simply apply in a deductive fashion the results of that analysis to any specific historical and political context. In noting these points, I am not saying that Rawls always made the right specific institutional and political judgements. He clearly misunderstood the welfare state (Weale, 2013). However, although there was always an abstract moment in his analysis, that should not be seen isolation from his recognition that the results of abstract analysis needed to be joined with historically specific political judgements when making practical evaluations.

A similar point can be made in connection with a second issue to which Forrester attaches importance, namely reparations for past colonial or racial wrongs, an issue that she takes to be outside the scope of liberal egalitarianism (pp. 132-135). In this context, consider the views of Charles Mills (2007), who sees the device of the Rawlsian original position as central to showing how, in illordered societies, there is a case for ending racial exploitation and redistributing the unjust proceeds of past exploitation. For Mills, it is precisely because the history of the racial contract of domination does not exemplify the conditions of a cooperative venture between equal citizens that we can identify why remedies are needed in relation to past injustice. It is not simply that the method of abstraction can be joined with the evaluation of historical wrongs. It is that the method of abstraction, when joined to suitable auxiliary premises, enables us not only to recognize the scale of historical wrongs as wrongs, but also to see what practical implications might follow.

\section{Conclusion}

In a thoughtful and insightful article, JR Lucas (1971) once pointed out that the differences between Pelagius and Augustine on the question of grace and free will were one of the few serious disputes where linguistic analysis could be of decisive help, requiring us to think about the logic of how divine grace can be reconciled with human freedom. Augustine had been right to ascribe his belief and Christian practice to God, but wrong to hold that he had had no say in whether he accepted God's grace. The reconciliation of the seeming opposites of grace and freedom required distinguishing between the various senses of the term 'cause'. The reconciliation of opposites is as much a problem in the design of economic and political institutions as it is in the metaphysics of the human will and divine grace. Admittedly in moving from the one to the other, we are moving from the drama of the individual soul to the collective organization of society, but in neither case can we find intellectual satisfaction by fixating on one side of a complex whole.

What, then, is involved in the act of analysis in terms of which such reconciliations are attempted? It is understanding the meaning of concepts and the way in which they stand to one another in particular bodies of theory. To understand the meaning of concepts and the logic of their inter-relationships requires adoption of the inner point of view, taking the premises and starting-points of the theories as 
given and seeking to work out the credence that can be placed in the result. It is the product of active minds.

How does an understanding of context supplement this understanding of meaning? In many ways. It may demonstrate why at a particular time some problems rather than others seem more pressing to active minds. It may indicate why certain theoretical options remain closed through the pressures of social convention or public opinion. It may suggest that the problems of any one generation are located in long-standing traditions of thought, as Nelson suggests. It may accompany an exposition of the intellectual development of a complex body of theory in relation to the political issues that prompted and shaped the theoretical thinking undertaken, as it does in Forrester's work. For these and other reasons, it will always be relevant in understanding a text to consider the social, political and intellect context in which that text is written.

None of this implies, however, that questions of meaning can be subsumed by the method of context. Whether we are talking about merit and free will or the dilemmas of democratic socialism, the logic of theory construction requires attention to the conceptual and normative assumptions of a theory independently of auxiliary assumptions. There is not a perennial philosophy; there are perennial dilemmas of individual and social life that require the methods of philosophy.

\section{Declaration of conflicting interests}

The author(s) declared no potential conflicts of interest with respect to the research, authorship, and/or publication of this article.

\section{Funding}

The author(s) received no financial support for the research, authorship, and/or publication of this article.

\section{ORCID iD}

Albert Weale (D) https://orcid.org/0000-0003-2623-9805

\section{References}

Augustine (1971 [417]) On the Proceedings of Pelagius in Saint Augustine: Anti-Pelagian Writings. Edited by P Schaff. Grand Rapids, MI: Wm B. Eerdmans.

Barry B (1965) Political Argument. London: Routledge and Kegan Paul. Bonner A (2018) The Myth of Pelagianism. Oxford: Oxford University Press.

Cohen J and Nagel T (2009) Introduction. In: Rawls J A Brief Inquiry into the Meaning of

Sin and Faith, with "On My Religion". Edited by T Nagel. Cambridge, MA: Harvard University Press, pp. 1-23.

Evans RF (1968) Pelagius: Inquiries and Reappraisals. London: Black.

Hart HLA (1961) The Concept of Law. Oxford: Clarendon Press.

Hick J (1968) Evil and the God of Love. London: Collins.

Lucas JR (1971) Pelagius and Augustine. Journal of Theological Studies NS 22(1): 73-85. 
Mills CW (2007) Contract of Breach: Repairing the Racial Contract. In Pateman C and Mills CW Contract and Domination. Cambridge: Polity Press, Chapter 4.

Nove A (1983) The Economics of Feasible Socialism. London: George Allen \& Unwin.

Pelagius (1991 [413]) To Demetrias. In: BR Rees (ed.) The Letters of Pelagius and His Followers. Woodbridge: The Boydell Press, pp. 29-70

Rawls J (1999) A Theory of Justice. Cambridge, MA: The Belknap Press.

Rawls J (2009) A Brief Inquiry into the Meaning of Sin and Faith, with "On My Religion". Edited by T Nagel. Cambridge, MA: Harvard University Press.

Rees BR (1988) Pelagius: A Reluctant Heretic. Woodbridge: The Boydell Press.

Scheffler S (2003) What is egalitarianism? Philosophy and Public Affairs 31(1): 5-39.

Sidgwick H (1981 [1907]) The Methods of Ethics. Foreword by J Rawls. Indianapolis, IN and Cambridge: Hackett Publishing Company.

Stump E (2001) Augustine on free will. In: Stump E and Kretzmann N (eds) The Cambridge Companion to Augustine. Cambridge: Cambridge University Press, pp. 166-86

Tawney RH (1964) Equality. Introduction by RM Titmuss. London: Unwin Books.

Tully J (ed.) (1988) Meaning and Context: Quentin Skinner and his Critics. Cambridge: Polity Press.

Weale A (2013) The property-owning democracy versus the welfare state. Analyse und Kritik 35(1): 37-54. 